Mobile Life: Biosecurity Practices and Insect Globalization

Nigel Clark

Lancaster Environment Centre,

Lancaster University, UK

Science as Culture, (2013) 22:1, 16-37

To link to this article: http://dx.doi.org/10.1080/09505431.2013.776366 


\title{
Mobile Life: Biosecurity Practices and Insect Globalization
}

\author{
Abstract \\ Recent decades have seen a series of high-profile public health crises involving viruses, \\ bacteria and other biological agents, together with escalating concern over impacts of \\ biological invasion on crops and ecosystems. In the context of intensifying globalization, \\ such hazards are being viewed as serious 'security' threats. For critical social theorists, \\ this growing concern with biosecurity at the global scale has worrying implications, in \\ that it promotes a state of fear over 'life itself' which is being used to justify heightened \\ surveillance and increasingly intrusive intervention. However, there are alternative \\ perspectives on living with adventitious and unpredictable biological life. For over a \\ century and a half, 'settler societies' such as Aotearoa New Zealand and Australia have \\ been grappling with the environmental and economic impacts of non-native organisms \\ running wild. Examining events surrounding an incursion of tussock moths in Auckland, \\ it is argued that biosecurity policy can also be viewed as a flexible and evolving response \\ to uncertainties associated with trans-located biological life. Furthermore, the \\ 'peripheral' tradition of sustained inquiry around the issue of which organisms belong in \\ which places leads us back to questions about the characteristics of insects themselves \\ and about the dynamics of the environments with which they interact. In this way, critical \\ thinking around biosecurity is opened to a depth of engagement with evolutionary and \\ geological processes that offer new dimensions to thinking about the 'biopolitics' and \\ 'geopolitics' of encountering life out of bounds.
}


Key words: insects, biosecurity, bioinvasion, biopolitics, settler societies, globalization.

'One the hallmarks of contemporary biodefense initiatives', announces philosopher Eugene Thacker, 'is the implosion of biology and war' (2005, unpag). This is how it may have seemed to the residents of eastern Auckland in October 1996, when Douglas DC-6 aircraft began flying overhead, so low they seemed to be barely clearing the rooftops. The planes - former military transporters - flew 23 sorties, each time dousing the leafy middleclass suburb of Kohimarama in a spray of commercial insecticide (Barlow and Goldson, 2002: p.199). The target of 'Operation Ever Green’ was a tiny population of non-native moths which had established itself over a few square miles. The \$NZ 12 million campaign, which also included extensive ground-based operations, was triggered by the discovery of an unfamiliar caterpillar by a sharp-eyed gardener. Having been identified by scientists of the New Zealand Ministry of Agriculture and Fisheries as the larva of Orgyia thyellina Butler - the white-spotted tussock moth - it was decided that the species posed a serious threat to horticulture, exotic forest plantations and native beech forests. After a speedy environmental impact study, the decision was made to exterminate the incursive moth population. 
As New Zealand biosecurity authorities concluded: 'Operation Ever Green was wound up in 1998, confident that it has achieved both its objective and a place in history as one of the most successful eradication programmes ever undertaken in an urban area' (Biosecurity NZ, 2008, unpag). Despite this apparent success, the level of public interest in the campaign, along with uncertainty over whether its costs were justified, and general fears of escalating biosecurity risks prompted a ministerial review (Barlow and Goldson, 2002: p.199). The title of the resulting report: New Zealand Under Siege (Office to the Parliamentary Commissioner for the Environment [OPCE]: 2000), gives an indication of the prevailing attitude toward invasive organisms in New Zealand, a country often credited with having the most stringent biosecurity regulations of any nation state (see Barker 2008: p.1599).

Formerly one of the most isolated landmasses on the planet, the islands of Aotearoa New Zealand have been the site of successive waves of introduced organisms, beginning with the arrival of Polynesian peoples around 1000 years ago, and intensifying after European settlement (Cook et al, 2002: p. 217). The ministerial review showed that exotic pests cost the New Zealand economy around $\$ 400$ million a year, while a further $\$ 440$ million is spent on border surveillance and on measures to contain or control invasive animals and plants which have become established (Williams and Timmons, 2002: p.176). Once considered primarily a problem of oceanic islands, there is now growing consensus amongst international researchers that the impact of biological invasion is a problem across the globe which is second only to changes in land cover in its threat to biological 
diversity (OPCE, 2000: p.19; see also Bright, 1999; Mooney and Hobbs, 2000; Davis, 2009; Pennings et al, 2010).

If not as stringently as New Zealand, many nation states are now intensifying their efforts to monitor and regulate the passage of non-native organisms into their territorial lands and waters. The threat posed by the spread of biological agents to the health of human beings, to agricultural plants and animals, and to the integrity of ecosystems is generally believed to be closely related to globalization. The idea that 'life itself' has inherently dynamic and unpredictable qualities is coupled with anxieties over the way that the increasing global interconnectivity is providing new opportunities for the dissemination of living things. Insects such as mosquitoes, aphids, wood-boring beetles and termites, and polyphagus - or generalist feeding - moths are high on the list of troublesome lifeforms which are well-equipped to take advantage of new pathways of dispersal. Their small size and large numbers, their great morphological and functional diversity, and their own capacity for both air-born and terrestrial mobility - in short, many of the properties that have made insects such an evolutionary success - render them especially difficult for human agents to regulate. At the same time, the propensity of insects to compete with humans for valued biomass, along with their role as parasites of larger organisms or as carriers of pathogenic microorganisms means that their colonisation of novel environments can be extremely costly.

As commentators in the social sciences have recently been arguing, the idea that biological agency poses a major threat may be emerging as one of the definitive political 
issues in a globalized world. 'Biosecuritization' - the attempt to protect established and valued life from emergent, transgressive and undesirable life - it is claimed, is now being established as a key imperative for developing new political technologies of surveillance and control. In this way, critical thinkers suggest, the globe in its entirety is emerging as arena of integrated practices, techniques and strategies whose aim is not simply to contain existing biological threats, but to anticipate and pre-empt new permutations of biological life that might yet unfold at some point in the future. In this way, life's own capacity for 'emergence', it is argued, is being used to justify a continuous state of emergency: a situation seemingly more conducive to military decisiveness than political deliberation.

The unleashing of the full exterminating force of Operation Ever Green might well be taken to epitomise the sudden imposition of a bio-security emergency. Furthermore, recent moves to extend New Zealand's biological surveillance and regulation beyond its own territory suggests that the imperatives of biosecuritization may be drawing the country in the direction of new political rationalities of the kind that are attracting critical concern.

But this is not the only way to interpret these engagements with the mobilizations of biological life or to make sense of the shifting responses of a relatively small nation, positioned on the former colonial periphery. Operation Ever Green and related strategies might also be seen as expressions of a more localized entanglement with runaway life, a pragmatic but also curious interest in the agency of biological life that has long been a 
part of cultural and material life in Aotearoa New Zealand and other settler colonies. This style of thinking about and thinking through the dynamics of life in novel environments has a considerable history of attending to the particularities of life-form and landform. Brought up to date and read creatively, it invites us to attend to both the fine-grained differences between organisms and the deep-seated spatio-temporal forces that shape physical environments.

Elaborating on the theme of translocated life that surfaces at various junctures in settler society discourse and practice, the paper turns to the question of what is specific to, and challenging about, the mobilization of insects. Without foreclosing on the political concerns of contemporary critical discourses on biosecuritization, it turns from the question of how insects are enrolled in the global interconnectivities orchestrated by our own species to ask about those capacities to traverse and transform 'the globe' that belong to the insect itself. In this way, the issue of how we might think about a case of invasive insects in the light of emergent practices of global biosecuritization is supplemented by another consideration: how we might rethink our own globalizing achievements in the light of another wave of 'globalization' that preceded our own efforts by some 130 million years. Moreover, once we begin thinking seriously about the characteristics of insects themselves and about the dynamics of the environments with which they have interacted, we are drawn into temporal and spatial scales which demand an engagement - whether practical or conceptual - with processes that exceed the 'biological'. The issue of insect globalization, the paper proposes, challenges us to 
expand our questioning of the politics of biological securitization to consider how human interactions with other species are framed by mobile and changeable geological forces.

\section{Conceptual background}

One of the reasons why biological invasion may have been relatively slow to ascend the global environmental agenda is that it is as much a question of the unabashed exuberance of living organisms as it as a matter of their vulnerability. With environmental politics initially coalescing around notions of the endangerment or loss of the natural world, there was a tendency to overlook problems arising out of a seeming excess of biological life. Early engagement by critical social thinkers with the environmental problematic did little to help. Here too, the focus was primarily on the 'end' or 'retreat' of nature. Social theorists, seeking to undermine the constant recourse to a grounding 'nature' in environmental thought and practice, made the claim that next to nothing of the biophysical world remained unaltered by human activity. As geographer Neil Smith asserted, 'no God-given stone is left unturned, no original relation with nature unaltered, no living thing unaffected' (1984: p. xiv). No less than was the case in environmental discourse, blanket pronouncements of nature's eclipse by social and cultural thinkers left little room to consider the possibility that the undiminished vitality of biological life might itself have troubling consequences.

The notion of a monolithic retreat of nature before the advances of human productive forces - in both its environmentalist and social scientific guises - was by no means 
restricted to the early-industrialising metropolitan centres. Development on the 'colonial periphery', especially in zones where European powers established settler colonies, also involved deep anxiety over the disappearance or despoliation of previously existing bio-physical formations. But in the temperate regions that girdled the Southern Hemisphere - including southern Africa, lower South America, Australia, New Zealand and smaller islands - attempts to impose European-style agricultural regimes also had ecological consequences distinct from those that accompanied industrialisation. Here, along with the closely related condition of rapid and frequently devastating changes in land cover, the unpredictable dissemination of introduced species quickly emerged as a problem of massive proportions (Clark, A: 1949; Clark, N: 2002).

Historian Alfred Crosby has described the organisms that were both accidently and intentionally transplanted from Europe to the 'new worlds' as 'a grunting, lowing, neighing, crowing, chirping, snarling, buzzing, self-replicating and world-altering avalanche' (1986: p.194). In New Zealand and Australia, especially, it was already apparent in the $19^{\text {th }}$ century that introduced species - including weedy plants, insects, rodents, feral livestock and game animals - were having serious impacts on local landscapes and on the species that were considered 'native' to these regions. What emerged in response might be thought of as a kind of proto-environmentalism, forged not only around a concern over the impact of settler land-use practices, but around the issue of what biological life itself could do when organisms found themselves at large in a strange land (Clark, 1999; 2003). 
The result is a wealth of debates, commentaries, tactics and policies that responded - in complicated and, occasionally, quite creative ways - to the predicament of life out of bounds. Many of these material and textual practices shuttle ambivalently between a desire to reproduce the natural conditions of the imperial centre (or even the wider world) in the settler colony and an equally fervent wish to protect, nurture and identify with the 'native' elements of an adopted homeland. With the ascendance of nationalist repertoires among settler populations, the latter impulse has prevailed - frequently resulting in an aggressive turn against introduced biota, especially when they are seen to be economically costly and/or a threat to 'indigenous' flora and fauna (Morton and Smith, 1999).

But in the interstices of an insecure nationalism, there have always been theorists and practitioners willing to engage in a more explorative relationship to the introduced species of the settler colonies. Emblematic of this more curious thematization of adventitious life are the writings of the farmer-naturalist Herbert Guthrie-Smith (1999[1921]), who, from the 1880s to the 1930s, documented the dynamics of every nonnative plant and animal that appeared on a single block of pastoral land on New Zealand's East Coast. Guthrie-Smith offered more than just an obsessive chronicle of weedy invaders. He sought, more imaginatively, to explore the experience and the potentialities of the mobilizing organisms themselves: 'Each was beyond the direct influence of man - outside his pale, free to select the route of its wanderings, its rate of increase, its climate....they were free to pursue a future unshackled by the past' (GuthrieSmith, 1999: p.382). Along these lines, Guthrie-Smith's writing considered the relations 
of different non-native species to each other and to native species, the geological and biological conditions underpinning the establishment of incursive biota, and the modes of conveyance particular to each organism. He also contemplated the more general effect of new forms of interconnection between places. Addressing the overall condition of biological life in the world as it appeared to be unfolding in his era, Guthrie-Smith deftly concluded: 'Space and time have been abbreviated' (1999: p. 421).

The work of Guthrie-Smith follows earlier speculation about the relationship between biological life in Europe and its 'antipodes', and anticipates an expanding literature on settler colony species trans-location that includes local writers and visiting overseas experts. From Thomson (1922) Clark (1949), Rolls (1969), and on to more recent work by Flannery (1994) and Low (1999), Australasian experience has played its part in understanding and addressing the vitality of transplanted biological life. Viewed collectively, this work opens up important questions both about the agency proper to the organisms themselves and about the mediating role of anthropogenic vectors and networks in setting new trajectories for biological life.

To put it another way, well before 'relational materialist' social thinkers working out of metropolitan centres made an issue of the co-productions of human and nonhuman actors (see Latour, 1993: p. 103; 2003: p. 37; Law, 2004: p.121), the mingling of heterogeneous agencies was as a matter of pressing practical and intellectual concern across the colonial periphery. Many settler society commentaries on unruly biota, it might be argued, were constitutively interested in the ways in which nonhuman agents resisted their enrolment 
in the grids and networks laid out for them. They were also, prefigured again by GuthrieSmith (1999: 346-8), more than willing to apply an analytical symmetry to humans and their nonhuman counterparts: being as comfortable describing plants and animals adhering to human pathways as they were tracking the way that human settlers followed paths established by earlier colonising species .

This is a deliberately de-centred route by which to arrive at the recent surge of work by critical social thinkers - predominantly based in northern metropoles - on irruptive biological agency and the responses it is engendering. While some of these writers have noted the diverse genealogies of the concern with 'biosecurity' - including the contribution made from the former colonial periphery (see Hinchliffe and Bingham, 2008a) - this literature elaborates primarily on relatively recent metropolitan thematizations of nonhuman agency, active materiality, and biological vitality. In ways that are much less developed in settler society prefigurations, it must be added, it draws the theme of hazardous biological agency into dialogue with critical theorizations of politics or governance in a globalising world.

As social scientific commentators have been noting, discourses and practices of biosecuritization are on the rise across much of the world and in many contexts. The handling of public health crises such as HIV/AIDS, avian influenza, SARS, foot and mouth disease, and the anthrax scare are being taken as indicative that hazards associated with biological life are taking shape as some of the preeminent `security' 
issues of our era (Collier et al., 2004; Dillon, 2007; Hinchliffe and Bingham, 2008a; 2008b; Fidler and Gostin, 2008).

Clearly, this is a more encompassing concern than bioinvasion. To a much greater degree than in the thematization of unruly biota in the settler societies, it is the human body which is seen to be at risk. Social theorists have suggested that rising unease about the vulnerability of individual and social bodies is linked to the ascendance of new techniques for manipulating 'life itself': procedures which bring formerly discrete biological beings into unprecedented proximity. Such 'developments' are not only experienced as having potentially harmful consequences, it is argued, they also promote ways of thinking about life in general which underscore its inherent potentiality to transform itself - to become other than it is (Cooper, 2006; Dillon, 2007). At the same time, a raft of uncertainties ranging from terrorism to climate change and economic instability are serving to highlight another set of dangerous 'porosities': those new forms of spatio-temporal intimacy that arise out intensifying globalization. As social science commentators propose, it is the intersection of these proximities - the boundary-effacing threats of a globalising world crossed with the novel sense of the transgressiveness of life - that are fuelling new anxieties: giving rise to a pervading sense that dangerous biological agents might suddenly emerge in any form, in any place, at any moment (Braun, 2007; Ali and Keil, 2008).

'Biosecuritization' is the term increasingly being used to connote the formalized procedures aimed at detecting and containing threats to the security of life posed by life 
itself - or by 'life-like properties' (Dillon, 2007: 13). It is not the attempt to reduce the danger of hazardous biological agents per se that seems to perturb critical social thinkers, so much as the way that this is being implemented and enforced on a global scale.

Unsurprisingly, social scientists schooled in actor network theories and related approaches which specialize in the study of the eventful admixture of diverse entities have their own deep-seated concerns over the interplay of biological agency and global networks. Where they tend to distance themselves from official framings of the biosecurity problem is in regard to the way that the latter deploy the threat of catastrophe in such a manner 'that security appears the only available response' (Braun 2007, p. 15).

This suspicion that the generativity of life is being presented as an unquestionable imperative to roll out strategies of management or governance draws critical thinkers into conversation with the work of philosopher and social theorist Michel Foucault, and especially with his concept of biopolitics. By `biopolitics’, Foucault refers to range of political techniques that emerged in early modernity with the aim of monitoring, managing and enhancing what had come to be seen as the unruly energies of the living human body (1981, 2007; Braun, 2007, p.8), Subsequently social theorists have supplemented Foucault's inquiries by proposing that in our own era biopolitics has expanded its remit to encompass not only human life, but all biological beings - and takes as its sphere of operations not just the territory of the sovereign state, but the globe in its entirety. As the threat of the uncontrollable vitality is extended to life in general, critics claim, global catastrophe is being used by the relevant authorities to justify new levels of surveillance, together with interventionist measures designed to be rolled out 
anywhere on the planet, without hesitation, using whatever means are deemed necessary (Dillon, 2007: p. 16). In this way, geographer Bruce Braun concludes, ‘Biosecurity weds biopolitics with geopolitics' (2007: p.23, see also Dillon, 2007: p.10-11, Hinchliffe and Bingham 2008a: p. 1548).

The claim that a biopolitics of security is now being wielded 'geopolitically' is advanced by critical thinkers as a way of stressing that the threat which a constant state of emergency poses to political liberties is increasingly geographically all-encompassing. But this invites the question of what exactly is meant by 'geopolitics' in this context. As Simon Dalby notes, disapprovingly, `(c)lassical geopolitics usually understands the geographical features of the earth's surface to be relatively stable, the stage as it were for the political dramas to unfold' (2007: 105). In their documenting of the unfolding of a novel political drama, it is not clear that critical theorists of biosecurity have gone much beyond this understanding. For all their sharp attunement to the dynamics of life - to the more-than-human agency and forcefulness that is expressed by the 'bio' in biopolitics there is as yet little evidence that the 'geo' in geopolitics is being afforded anything like the same degree of efficacy. The trouble with this missed opportunity is that it concedes the merger of bio- and geo-politics to the opposing camp, foreclosing on the potential to rework this conceptual coupling for other ends. Or to put it another way, it leaves critical thinkers oddly bereft of alternative imaginings of the interplay between biological life and the 'geographical features' of the earth. 
This brings us back to the rather more grainy and localised foci that can be found amongst settler society engagements with wayward life. For in variants of the 'peripheral' tradition, it is not only the mobilisation of life itself which make a difference, but also the mobilisations of the earth. As we turn to the specificities of Operation Ever Green, and New Zealand biosecurity policy more generally, it is important to keep in mind that critical metropolitan concern with the machinations of global governance in an era of biological anxiety may not tell the whole story. And that in order to follow the trajectory of mobilizing insects - not only into the domain of contemporary biosecurity practice, but deep into 'global' dynamics of a very different kind - we might wish to redeem some of the insights of an older lineage of theorizing nonhuman agency.

\section{Securing New Zealand against the Tussock Moth}

As the 2000 ministerial review on biosecurity concluded, there are so many species which could potentially arrive in New Zealand that it is impossible to predict the likelihood or the consequences of their establishment. 'The only certainty is that biosecurity breaches and incursions will inevitably occur despite measures to prevent them (Office to the Parliamentary Commissioner for the Environment [OPCE], 2000: p.

21, italics in orig.). Prompted in large part by the white-spotted tussock moth event and a 1999 incursion by the Australian painted apple moth, the review pushed forward moves already in process toward a single, integrated biosecurity system under the auspices of a minister of biosecurity (Barlow and Goldson, 2002: p. 199; Cook et al, 2002: p. 229). 
Events surrounding the incursion of Orgyia thyellina Butler can be seen as both a stimulus to an extension of techniques for monitoring biological agents and a reinforcement of the necessity of decisive, well-executed intervention when biosecurity systems are breached. To what extent, we will now be asking, do these intensifications of an already stringent national biosecurity policy constitute a shift towards the continual state of emergency that social and political theorists argue now characterizes global biosecuritization measures? And to what degree might we take such developments as indicative of both a change in the practice of politics - and in the conceptualization of life itself?

As was suggested at the beginning of the paper, Operation Ever Green displayed some conspicuous features of the kind of 'implosion of biology and war' that concerns progressive thinkers; a theme that has been explored in historical depth in the US context by Edmund Russell (2001, see also Palladino, Mitman, Jansen and Russell, 2003). This is more than a matter of a suburban populace being exposed to military-styled operations, and to the prodigious application of chemicals that Russell documents. Operation Ever Green belongs to a more recent turn, in which biological life itself is enrolled in the assault on life-out-of-place. The insecticide Foray 48B used to kill the caterpillars, previously deployed extensively in urban contexts in North America, includes the bacterium Bacillus thuringiensis kurstaki - which in its natural habitat targets the larvae of moths and butterflies (Biosecurity NZ: 2008). In order to identify the range over which the incursive population had established themselves, extensive use was made of pheromones of Orgyia thyellina Butler to attract individuals of the species. Pheromones 
were again deployed as bait in ground-based operations to trap moths, and for ongoing monitoring of the effects of the eradication programme. Mass release of sterilised male moths was also an integral part of the containment strategy (New Zealand Biodiversity, undated; Brockerhoff et al, 2006).

Advances in biotechnology are also playing a part in the tightening up of surveillance and detection. One of reasons why the white-spotted tussock moth was not considered a potential pest until its apprehension in Auckland was the difficulty of distinguishing this species morphologically from related species in the early life stages. This meant that records of the arrival of moths - usually based on egg clusters intercepted in incoming international freight - had little accuracy at the species level, which in turn put severe limitations on the suitability of quarantine systems (Armstrong et al 2003: p. 17). However, the development of molecular-based of DNA identification - referred to as DNA "barcodes" - now enable scientists to confidently distinguish between species at the egg-stage (Brockerhoff et al 2006: p. 265). A 2000-2002 DNA `bar-coding’ study of intercepted moth egg-masses, revealed that, while the vast majority were - as expected gypsy moths (107 out of a total of 116). However, two egg-masses which would have previously been assumed to be gypsy moths turned out to be white-spotted tussock moths (Armstrong et al, 2003: 18). As research scientists concluded: 'Extending this approach for the identification of other insects threatening New Zealand's biosecurity ... would be valuable, empowering biosecurity authorities to be more anticipatory and focused' (Armstrong et al, 2003: p.19). 
While accurate distinction between closely-related moths enables scientists to respond to incursion events with the correct pheromone lures, it also helps identify the pathways along which species have travelled. DNA testing confirmed earlier suspicions of the likely vector of the white-spotted tussock moth incursion which surfaced in eastern Auckland. Nearly all the intercepted egg-masses in the 2000-2002 study, including the white-spotted tussock moths, were found in second hand motor vehicles imported from Japan (Armstrong et al, 2003:p. 19). Increasing confidence in tracking modes of transmission, in this way, has important implications for extending monitoring and regulation of biological agents beyond the borders of the nation-state in question, as does the proliferation of the digital networks and data-bases through which DNA bar codes and other bio-information circulate (see Braun, 2007: p. 21). This takes us from the 'biologization' of security, to another key element in the critical concern over the conjunction of biopolitics and geopolitics: the increasingly extra-territorial reach of strategies of biosecuritization.

For all the success of Operation Ever Green, eradication programmes are extremely expensive, and are viewed as a last resort by biosecurity policy-makers and practitioners (Brockerhoff et al, 2006: p. 267). Despite increasing prioritization of biosecurity, authorities are well aware that only a fraction of mail, air and sea cargo is properly examined. Of the 360,000 sea-born containers entering New Zealand in 1999-2000, for example, only a quarter were inspected, of which one fifth were found to contain undeclared plant or animal material: figures which give an indication of the regularity of the incursion of unmonitored biological agents (Cook et al, 2002: p. 229). The preferred 
response is to try and pre-empt incursion events, increasingly entailing what the 2000 ministerial review refers to as 'monitoring at the pre-entry phase' or 'preborder controls' (OPCE, 2000: p. 21). Such extra-territorial measures include inspection and sanitization of cargo at ports of origin: strategies facilitated by the recent setting up of bilateral quarantine arrangements with Pacific island nations and other regular trading partners (Cook et al, 2002: p. 238). At the global level, this involves New Zealand's full participation in multilateral environmental accords such as Cartageña Protocol on Biosafety (2000), and the contribution of local scientists to the Global Invasive Species Programme, which seeks to identify key pathways of bioinvasion and to advance cooperation in the regulation and management of mobile life (Cook et al, 2002: p. 229).

\section{Reconsidering the Critique of Biosecuritization}

The idea of 'pre-emption' of biological threats - as a kind of reaching forward in time to grapple with a hazardous liveliness that is always emerging - is viewed by critical social thinkers as axial to the new geopolitics of biosecuritization. When this is coupled with claims about the supranational spatial reach of securing practices, the result can be a vision of political technologies that are utterly boundless and all-encompassing in their

effects. While some theorists see such forms of power as cleaving to a militaristic logic, others assert that the quest for global biosecurity is further implicated with ascending forms of speculative and financial capitalism (see Cooper, 2006). In this way, much 'progressive' social engagement with contemporary biosecurity regimes radiates a sense 
of retreating political possibility, of contracting spaces of autonomy or resistance. This is a disposition often abetted by the ready extrapolation of the Foucauldian rhetoric of discipline, control and surveillance - beyond its original context of human bodies under duress to encompass the biosphere in its entirety.

Taking issue with the repressive and totalizing vision of much of metropolitan musing over the geopolitics of biosecurity, geographer Kezia Barker claims that contemporary policy in New Zealand 'is more mobile, flexible, complex, and decentred than these critical discourses allow for' (2008: p. 1611). A key point in Barker's argument is that citizens are regularly consulted in the setting policy agendas, and wherever possible involved in implementing these policies. This is seems to be born out in the case of Operation Ever Green, where local cooperation -from the initial identification of the incursive species through to support of the eradication process - was credited with playing a major part in the success of the programme (see OPCE, 2000: p. 8). Or as the New Zealand Farm Forestry Association reports: `Extensive consultation and communication with the affected community became a foundation stone of the programme and was integrated with science and operational advice as the base from which all other action was undertaken'(NZ FFA; 1998: unpag). ${ }^{\text {i }}$

Barker also draws attention to the fluidity of the categories employed by New Zealand biosecurity authorities. This, she suggests, manifests itself in the pragmatic and shifting designations of which non-native species should be tolerated and which should be controlled or eradicated - an approach which allows for the fact that some incursive 
populations may, in certain contexts, come to provide valuable ecosystem services (Barker, pp. 1603-4; see also Cook et al, 2002: p. 221). This flexibility, Barker proposes, reflects the historical depth of biosecuritization practice in Aotearoa New Zealand which encompasses a century and a half of evolving policy, legislation and implementation measures (2008: 1598, 1611-12). And these practices seem to be still evolving. As the 2000 ministerial review makes clear, learning from both successes and failures continues to be a vital part of the current strategy. In the words of the report: 'Agencies should ... be willing to consider the value of 'learning by doing' when faced with a new type of incursion' (OPCE, 2000: p. 12). The review also contains enough equivocation over trade liberalization to unsettle any presumption of a straightforward fit between the political rationalities of biosecurity and the current logic of capital. Indeed, if it were to be worked up as an political issue, the willingness of the report to countenance proposals that biosecurity threats might justify moves to `support 'safe trade' as opposed to 'free trade'(see OPCE, 2000: p. 70) provides a potentially powerful platform from which to challenge current political-economic priorities.

While these are all valid reasons to question what Barker (2008: p. 1611) refers to as the 'prevailing anti-governance tone' of critical discourses on biosecurity, there are ways we might extend this sense of an alternative 'peripheral' engagement with the generativity of life that offer something more than critique of critique. What we need to take more seriously, I would suggest, are the questions which are being asked, and which have been asked for some time, about what kinds of living things pose the most danger to extant ecosystems, and why they do. The recognition by biosecurity authorities that there will 
continue to be cases of accidental translocation of species, no matter how stringent the precautions, together with the acknowledgement that there are limits to the resources available to contain incursive populations is encouraging a focus on 'pathways' rather than individual organisms (OPCE, 2000: p. 49). Thinking about pathways is more than a matter of considering the vectors or media of translocation: it also raises questions about the specificities of host environments, and about the characteristics of different classes or categories of incursive organism. And in this way we return to the issues of the characteristics of insects themselves, the relationships or 'assemblages' they forge with other living things, and the inorganic environments in which they find themselves. How does it matter, among other things, that insects have wings? And what difference does it make that Aotearoa New Zealand is formed of oceanic islands?

\section{Insects and Nonhuman Agency}

The white-spotted tussock moth is a native species of East Asia. While not considered a pest in the regions it currently inhabits, the decision to eradicate east Auckland's incursive population was based on evidence of the caterpillars' polyphagus consumption of biomass. Tests showed that its defoliating capacities posed a potential threat to five major crop plant groups as well as New Zealand's native black beech: Nothofagus solandri (NZ FFA, 1998: unpag). The moth is also known to be a strong flyer, and scientists estimated that left uncontrolled it would spread throughout the whole country in five to ten years (NZFFA, 1998: unpag). 
This small but crucial detail about the insects own dispersive capabilities reopens a theme central to the writing of Guthrie-Smith and his successors in the settler society engagement with wayward life: the vital role of the various mobilities which belong to biological life itself. In this regard, insects arguably deserve a greater attention than they have yet received in this literature as the class of animals which pioneered flight, and which remain, as entomologists would remind us, the most versatile and acrobatic aviators of the natural world (Grimaldi and Engel, 2005: p. 27). Flight, first achieved in the Carboniferous era some 300 million years ago, has enabled insects to extend their range - and to radiate out into innumerable niches (Grimaldi and Engel, 2005: p. 155, $160,188)$.

But flight alone does not explain the unprecedented geographical and morphological radiation of insects. The weeds that enthralled Guthrie-Smith, along with most of the crop plants that humans rely upon, and indeed some $90 \%$ of all terrestrial plant-life, belongs to the phylum of angiosperms or flowering plants. And the vast majority of this flora would cease to exist without insect pollination. At the same time, nearly half of all insects feed on flowering plants. The alliance between insects and angiosperms, forged over 130 million years ago, has been the key to the evolutionary success of both partners (Grimaldi and Engel, 2005: p. 607, see also Nuridsany and Perennou, 1997: p. 98) ${ }^{\mathrm{ii}}$.

While the insect-flowering plant assemblage reigns on all landmasses but Antarctica, not all insect orders are represented everywhere on the planet. There are limits to insect 
mobilization and radiation. Along with the gypsy moth, tussock moths belong to the family Lymantriidae, members of which are found on every continent apart from Antarctica: New Zealand being one of the largest landmasses that does not naturally host Lymantriids. While some members of the genus Lepidoptera - moths and butterflies achieve migrations of thousands of miles, such mobilizations tend to follow set paths. In many cases, geophysical barriers, especially oceans, continue to play an important part in conditioning the natural distribution of insects - over extensive spans of geological time.

The flip side of the mobility story in the southern periphery's transgressive life literature is the exploration of the theme of isolation. The role of insularity - manifest as a particularly high rate of endemism of terrestrial organisms - has featured prominently in the New Zealand strain of this tradition. As biologist Charles Elton noted in the classic Ecology of Invasions by Animals and Plants - which drew extensively on evidence from the southern temperate settler societies - 'New Zealand is the most special of special cases' (1958: p. 73). By this, he referred not only to the exceptional spatio-temporal distance between these islands and the nearest landmasses, but also to the suddenness with which the arrival of humans and their accompanying organisms punctured this oceanic seclusion.

While a certain 'nationalist' inflection of New Zealand naturalism has repeatedly fallen back on the idea that the islands constitute a once unique and unsullied relic of the ancient continent of Gondwana (Craw, 1990), the challenge of deciding which organisms belong where is helping push the issue of geological origins in rather different directions. 
And this, I want to argue, has potentially important implications for thinking about both the 'bio' in biopolitics, and the 'geo' in geopolitics. As New Zealand biosecurity advisor Rachel Garthwaite (2002) observes, polyphagus insects from the Northern Hemisphere such as members of the Lymantriidae family - are now known to pose a threat to native flora of New Zealand: this being the basic scenario informing Operation Ever Green. But Garthwaite makes a further claim. Recent research by the Department of Conservation, she reports, concluded that insects which originate in temperate Southern Hemisphere regions such as Australia, South America and southern Africa pose a far greater threat: 'These countries have floristic assemblages similar to species in New Zealand and invertebrates and pathogens from these countries are therefore more likely to be adapted to the particular characteristics of the New Zealand flora' (Garthwaite, 2002: p.11)

The question as to why there are similar biotic assemblages ranging across the widely separated landmasses of the southern hemisphere is an important one - and more complex and contested than it may first appear. The short answer derives from the study of plate tectonics, which shows that the landmasses in question were formerly part of the great southern continent of Gondwana - and that they have drifted apart, carrying related floristic and faunal assemblages with them as they have moved. With regards to the landform now known as New Zealand or Aotearoa, however, there is a more complicated - and by no means universally accepted answer. By looking closely at both the geological composition and the biotic assemblages of the island arc, some life and earth scientists argue that Aotearoa New Zealand is made up of heterogeneous terranes - or crustal fragments - mostly from sources other than Gondwana. Like many other landmasses, it is 
claimed, these islands have no single origin: they are a conglomerate of varied geological processes, including orogenic forces (uplifting and downlifting) erosions and accretions, and the drifting and suturing together of terranes arriving from several different directions (see Craw, 1985) As entomologist and biogeographer Robin Craw puts it:

Aotearoa was formed by convergent forces radiating out from at least three oceanic spreading centers. This triple plate junction is a complex mosaic of numerous terrains of disparate origin, formed in widely spaced settings, and then welded together and metamorphosized by immense tectonic forces. New Zealand is a biogeographic/geological composite or hybrid area, an orogenic collage of fragments...' (Craw and Hubbard, 1993: p.32).

By this reading, the isolation which Elton and so many others have foregrounded, while significant, may not as definitive as most life scientists and many cultural commentators have tended to assume. As Craw and a handful of other biogeographers have proposed, there may be no good reason to treat 'New Zealand' as a coherent unit or natural biogeographic entity at all. Rather, New Zealand's biological community appears to be profoundly differentiated, reflecting the multiple origins of the islands' geological components. And in this way, more so than it shows the effect of isolation, the characteristics of the country's various biotic assemblages reveals pronounced affiliations with the biota of the regions to which each fragment once belonged (Craw, 1985; Cooper, 1989; see also Clark, 2012) 
This is an account which has been corroborated by evidence of the distribution of the Lepidoptera family. As entomologist John Dugdale observes, there are 1750 species of Lepidoptera in New Zealand - the vast majority being moths, with 37 of a global total of 120 families represented (1989: p.679). While some $90 \%$ of these species are endemic, with only 64 species that are naturally found elsewhere, all these local insects have family members on other land masses. Dugdale supports the view that most moths rafted to their current locations on mobile terranes, though a small minority have arrived by flying from Australia (1989: p. 682). Based in part on the identification of kinship between different families of New Zealand Lepidoptera and various relatives in Australia, Papua New Guinea, South America and New Caledonia, he proposes that contemporary New Zealand is composed of two main terranes that have travelled great distances from the west and the east, compressing two narrower terranes: 'These two compressed terranes may have carried groups (of Lepidoptera) with a western Pacific distribution, or an essentially Australian-eastern Pacific distribution comparison of species (Dugdale, 1989: 685). While Dugdale concedes that elements of conjecture remain, he concludes 'The Lepidoptera appear therefore to accord with the view of Craw (1985), that New Zealand is a composite region, composed of accreted terranes' (1989: p.686).

If we are to at least provisionally run with this thesis, the issue of which non-native moths pose the greatest threat to Aotearoa New Zealand appears as a complicated one. If the strategy of Biosecurity New Zealand is to focus on identifying major pathways and anticipating possible impacts - rather than seeking unequivocally to exclude all non- 
native species - then the question of how different orders or families of organisms have come to inhabit the island arc is profoundly important. This opens up inquiry to another set of pathways: those taken by the species referred to as native. These trajectories require knowledge of the mobilization of species themselves. But this in turn calls for an understanding of the complex mobilities of the crustal plates and fragments on which assemblages of biota have travelled. In the case of the white-spotted tussock moth, biosecurity authorities are dealing with a species whose family Lymantriidae appears not to have been among the 37 Lepidopteran families that rafted to the current New Zealand on a set of terranes that have converged from very different directions (see Dugdale, 1989).

Both the specificities of the eating habits evolved by the Lymantriidae in their native landmasses and the fact that these host plant-insect relationships are not a natural part of the composite biotic assemblages of the islands of New Zealand ought to be significant in the shaping responses to Lymantrid incursions. For our purposes however, the details are less important than the more general implications of understanding insect pathways - in the broadest sense - for rethinking the issue of biosecuritization on a global scale. In short, if the question of which insects belong where is pursued in a sustained way, we find ourselves being drawn towards a much more literal and substantive sense of the 'geo' in geopolitics than most current uses of the concept would permit.

Perhaps the most important implication of this for biosecuring practices is that it suggests that less emphasis should be placed on existing geophysical formations, and more 
attention given to the dynamic geological processes through which extant landmasses have been formed (see Grehan, 1989). While the claim that current political boundaries should not be taken for granted is routine in critical thought, there is still a tendency shared with many biosecurity practitioners - to assume that the landforms these human territorial markings are inscribed upon form stable and coherent entities. But as soon as we broach the question of which life-forms belong where, the temporalities which open up encompass profound geological mobility, upheaval and reconfiguration. And while the islands of Aotearoa New Zealand may express an especially tumultuous geologic history, the biogeography of every region can be seen to manifest a succession of geomorphic events.

A clearer sense of the geological pathways and junctures that have shaped extant landmasses cannot provide a rulebook for the level of defense that ought to be applied to each potentially incursive genus or species. But it can offer indications as to where efforts might be focussed. One of the basic implications is that in the case of a composite geological formation, mobilization of a species across the divisions within the existing landmass may be just as risky, or even more so, than the arrival of an 'exotic' species (see Cooper, 1989; Grehan, 1989). An understanding of the extent to which affiliations between species - or entire biotic assemblages - can bridge great distances can point up the risk of pre-adaptation on the part of certain potential new arrivals. On the other hand, it also has implications for restorative ecological strategies, for it suggests possible sources of substitutes for species that have become extinct on a specific landmass or terrane. 
Moreover, closer attention to the relationship between the mobilities of life and landform may offer insights at a time of human-induced climatic instability, especially when we consider the gathering evidence that, at a global scale, rapid climate change is accompanied by significant increases in seismicity, volcanism and other forms of geological upheaval (see McGuire, 2012). In this context, decisions about what species should be relocated, or permitted to relocate themselves, in changing climatic zones need to take account of the role played by changing sea level and other geologic repercussions of past climate change on current distributions and assemblages of biological life. Or to put it another way, practices concerning biological life might benefit from an alternative critical imagining of a dynamically interactive bio- and geo- politics.

\section{Conclusion}

In many respects, Operation Ever Green and the related priorities laid out in New Zealand's 2000 ministerial review belong amidst the unfolding political rationalities of global biosecuritization that 'metropolitan' critical social scientists are now interrogating with some unease. In other regards, however, biosecurity strategies in Aotearoa New Zealand elaborate on elements of an earlier 'peripheral' tradition, with its characteristic experiments and improvisations, its partiality and its pragmatism. The presence of these other characteristics of national biosecurity ought to raise some serious doubts over the extent and generality of the new political rationalities and imaginings of life that are being described in some critical accounts of global biosecurity 
Those texts and practices that coalesced around the encounter with adventitious organisms across the former colonial periphery, I have been suggesting, are a rich resource for thinking with and through the mobilities of biological life - a body of work that in many ways anticipates some of the more creative contemporary social scientific writing on materiality, vitality and heterogeneous agencies. But whereas the recent metropolitan critical engagement with `more-than-human’ agency generally contents itself with tracking the co-enactment of the human and its extra-human others (see Clark, 2011: Ch. 2), peripheral approaches are more likely to push on through the humannonhuman interface and explore realms comprised entirely of nonhuman entities and processes. In this context, grappling with the material impacts of human translocation not only includes a consideration of biotic mobilities and dispersions, it often involves a further opening onto the deep spatio-temporal and profoundly inhuman dynamics of earth processes.

When insects of any order are the object of our biosecurity concerns, I would argue, we are obliged to follow this lead and delve into domains that are utterly devoid of human presence. That numerous Lepidoptera have rafted across oceans to their current location on drifting fragments of the earth's crust is a reminder that insects belong to geological space and time, vastly predating the current arrangement of continents and seas. For those social theorists currently in thrall to the various globe-spanning conjunctions of human and nonhuman entities, it is vital to recall that for at least 129.99 million of the last 130 million years the most significant world-altering alliance has been that between insects and flowering plants: one that did not involve humans in any sense at all. 
Moreover, as entomologists remind us, the equilibrium of the earth's biosphere continues to depend on the cooperation of insects and angiosperms. If insects were removed from the earth, as David Grimaldi and Michael Engel explain:

Most angiosperms would die, the ensuing plant wreckage would molder and ferment ... soil depleted of nutrients would barely be able to sustain the remaining plants; erosion would choke waterways with silt. Vast tropical forests of the Amazon, Orinoco, Congo, and other river basins would die off, and the earth's atmosphere and oceans would become toxic (2005: p.5-6).

Aside from a few biotic assemblages of very recent origin, the removal of Homo sapiens would have few deleterious impacts on most biotic communities - and in all likelihood a great many positive consequences for threatened ecosystems and species. To put it simply, human existence depends upon insects and their assemblages to a far greater degree than they rely upon us. This yawning asymmetry between our species and the insect-angiosperm alliance probably goes some way towards explaining the exorbitant amount of socio-material resources it required to dislodge a tiny colonist population of Lepidoptera scattered across a few square miles. It hints at why human agents had to go to extraordinary lengths to mimic the quite ordinary capacities of insects at every turn from taking to the air, spreading pathogenic micro-organisms and deploying speciesspecific pheromones - in order to have any chance of containing insect vitality. Even 
though the presumption was that the tussock moth was the organism which was 'out of place', it was 'we', as human agents, who found ourselves in the position of confronting insects on their own terrain.

And in a sense, the vast majority of terrestrial environments are indeed insect-angiosperm terrains. Perhaps the more important point, then, to take from an acknowledgement of the radical asymmetry between humankind and insects is that 'our' own globalization would be inconceivable without the prior global radiation and dispersion achieved by the angiosperm-insect alliance: a planetary networking facilitated by the insect's capacity for air-born mobilization working in concert with the earth's own crustal mobility. Some of the more searching social scientific work on biosecurity - drawing on vitalist currents in the work of Foucault, Deleuze and Guattari (1987) and others - acknowledges the ultimately intractable force of biological life. But this embrace of vitality needs to be articulated with more specificity and rigour, which also implies pushing beyond biological life to engage with geological or inorganic processes. If we are to follow the insects themselves, or any other forms of life for that matter, then very soon we are going to be drawn into domains where human-nonhuman relations cease to have any purchase, and it is unequivocally inhuman processes which are responsible for world-shaping and ordering activity.

We have come a long way from a handful of moth larvae making an appearance in a suburban backyard on a temperate Southern Hemisphere island. If we are to begin to make sense of the way insects take advantage of global vectors and networks set up by 
human agents, I have been arguing, we also need to understand how insects have come to be in the places they now inhabit. In this way, biopolitical issues - questions about composing and modulating our relations with our own vitality and that of other living things - also raise questions of geopolitics, as indeed critical social thinkers have suggested. But if we permit insects to be our guides and our provocation, 'geopolitics' needs to refer to something more than the governance of a planet connected, divided or ordered by our own species. It needs to engage, quite literally and substantively with earth processes: with geology, geomorphology and geophysics (see Clark, 2012). Only then might critical discourses on biosecuritization aspire to a fusion of 'biopolitics' and 'geopolitics' worthy of the terms. What exactly such an extension of political thought might look like is still to be worked out, but what we might hope for are expressions that reflect conjunctions of earth, life, and belated human agency that are specific to place or region.

At once riding out profound transformations in the earth's surface and effecting their own dramatic changes in terrestrial environments, insects remind us just how much our own world-ordering practices are responses to conditions not of our own making. This is a lesson for which there is much to learn from the on-going engagement with the unsettled life of the settler societies. At the same time, a sense of the flexibility, partiality and improvisatory nature of these 'peripheral' engagements might help prise open some spaces of possibility within the otherwise totalizing and immobilizing vision of much metropolitan critical discourse on biosecurity. 


\section{References}

Ali, S. H. and Keil, R. (2008) 'Introduction: Networked Disease', in Ali, S. H. and Keil, R. (eds) Networked Disease: Emerging Infections in the Global City (Chichester, West Sussex: Wiley-Blackwell).

Armstrong, K., McHugh, P., Chinn, W., Frampton, E. and Walsh, P. (2003) `Tussock moth species arriving on imported used vehicles determined by DNA analysis', New Zealand Plant Protection 56: pp. 16-20.

Barker, K. (2008) 'Flexible boundaries in biosecurity: accommodating gorse in Aotearoa New Zealand', Environment and Planning A 40, pp. 1598 -1614.

Barlow, N. and Goldson, S. (2002) 'Alien Invertebrates in New Zealand', in Pimental, D. (ed) Biological invasions: economic and environmental costs of alien plant, animal, and microbe species (Boca Raton, FL : CRC Press) pp. 195 - 216.

Biosecurity NZ (2008) ‘White-Spotted Tussock Moth’ [online]. Available at: http://www.biosecurity.govt.nz/pests/white-spotted-tussock-moth (accessed 16 May 2010).

Braun, B. (2007) 'Biopolitics and the Molecularization of Life', Cultural Geographies 14: pp. 6-28. 
Bright, C. (1999) Life out of Bounds: Bioinvasion in a Borderless World (London: Earthscan).

Brockerhoff, E., Liebhold, A. and Jactel, H. (2006) `The ecology of forest insect invasions and advances in their management', Canadian Journal of Forest Research 36 pp. 263-268.

Clark, A, H. (1949) The Invasion of New Zealand by People, Plants and Animals.(New Brunswick, NJ: Rutgers University Press).

Clark, N. (1999) 'Wild Life: Ferality and the Frontier with Chaos”, in Quicksands: Foundational Histories of Australia and Aotearoa New Zealand, eds K. Neumann, H. Ericksen and N. Thomas. (Sydney: University of New South Wales Press).

Clark, N. (2002) `The Demon-Seed: Bioinvasion as the Unsettling of Environmental Cosmopolitanism', Theory Culture \& Society 19 (1-2): pp. 101-126.

Clark, N. (2003) 'Feral ecologies: performing life on the colonial periphery', in Szerszynski, B., Heim, W. and Waterton, C (eds) Nature Performed: Environment, Culture and Performance (Oxford: Blackwell) pp. 163 -180

Clark, N. (2011) Inhuman Nature: Sociable Life on a Dynamic Planet (London: Sage). 
Clark, N. (2012 forthcoming) 'Rock, Life, Fire: Speculative Geophysics and the Anthropocene', Oxford Literary Review.

Craw, R. (1985) `Classic problems of Southern Hemisphere biogeography re-examined: Panbiogeographic analysis of the New Zealand frog Leiopelma, the ratite birds and Nothofagus', Journal of Zoological Systematics and Evolutionary Research, 23: pp 1-10.

Craw, R. (1990) 'Visible Difference: Nationalist Repertoires and the Semiotics of Place in New Zealand Science' Antic_8, pp. 4-7.

Craw, R. and Hubbard, G. (1993) `Cross Pollination: Hyphenated identities and Hybrid Realities (or ALTER/NATIVE to What?)', Midwest 3 pp. 32-3.

Collier S., Lakoff A., and Rabinow P, (2004) `Biosecurity: towards an anthropology of the contemporary', Anthropology Today 20 (5) pp. $3-7$.

Cook, A., Weinstein, P. and Woodward, A. (2002) `The Impact of Exotic Insects in New Zealand' in Pimental, D. (ed) Biological invasions: economic and environmental costs of alien plant, animal, and microbe species (Boca Raton, FL : CRC Press) pp. 217 - 239.

Cooper, R (1989) 'New Zealand Tectonostratigraphic Terranes and Panbiogeography', New Zealand Journal of Zoology 16 (4) pp. 699-712. 
Cooper, M. (2006) 'Pre-empting Emergence: The Biological Turn in the War on Terror', Theory Culture \& Society 23 (4) pp. 113-135.

Crosby A, (1986) Ecological Imperialism: The Biological Expansion of Europe 900 1900 (Cambridge: Cambridge University Press).

Dalby, S. (2007) `Anthropocene Geopolitics: Globalisation, Empire, Environment and Critique', Geography Compass 1 (1) pp. 103-118.

Davis, M. (2009) Invasion Biology (Oxford: Oxford University Press).

Deleuze, G. and Guattari, F. (1987) A Thousand Plateaus: Capitalism and Schizophrenia. (Minneapolis: University of Minnesota Press).

Dillon, M. (2007) `Governing Terror: The State of Emergency of Biopolitical Emergence', International Political Sociology 1, pp. 7-28.

Dugdale, J. (1989) `New Zealand Lepidoptera: basic biogeography’, New Zealand Journal of Zoology, 16, pp. 679787.

Elton, C. (1958) The Ecology of Invasions by Animals and Plants (London: Methuen). 
Fidler, D. and Gostin, L.(2008) Biosecurity in the Global Age: Biological Weapons, Public Health and the Rule of Law. (Stanford, CA: Stanford University Press).

Flannery, T. (1994) The Future Eaters: An Ecological History of the Australasian Lands and People (Kew, VIC: Reed Books).

Foucault, M. (1981) The History of Sexuality. Volume 1: An Introduction (Harmondsworth, Middx: Penguin).

Foucault, M. (2007) Security, Territory, Population: Lectures at the College de France 1977-1978 (Basingstoke, Hampshire: Palgrave Macmillan).

Garthwaite, R. (2002) `Beyond the vertebrates - what are the threats to forests in the conservation estate from new organisms?' NZ Journal of Forestry, August, pp. 10 - 11 [online] Available at: http://www.nzjf.org/free_issues/NZJF47_2_2002/9E948B06-E7534ECD-9DF3-7178982B850A.pdf (accessed 1 November 2011)

Ginsburg, G. (2006) `Aerial spraying of Bacillus Thuringiensis Kurstaki (Btk)', Journal of Pesticide Reform 26 (2) pp. 13-16.

Grehan, J. (1989) 'Panbiogeography and Conservation Science in New Zealand', New Zealand Journal of Zoology 16 (4) pp. 731-741. 
Grimaldi, D. and Engel, M. S. (2005) Evolution of Insects. New York: Cambridge University Press.

Guthrie-Smith, H. (1999 [1921]) Tutira: The Story of a New Zealand Sheep Station (Auckland: Godwit).

Hinchliffe, S. and Bingham, N. (2008a) `Securing Life: the Emergent Practices of Biosecurity', Environment and Planning A 40: pp.1534-1551.

Hinchliffe, S. and Bingham, N. (2008b) `People, Animals, and Biosecurity in and through Cities' in S. H. Ali and R. Keil (eds) Networked Disease: Emerging Infections in the Global City (Chichester, West Sussex: Wiley-Blackwell).

Latour, B. (1993) We have Never been Modern (Cambridge, MA.: Harvard University Press).

Law, J. (2004) After Methods: Mess in Social Science Research (London and New York: Routledge).

Low, T. (1999) Feral Future. (Ringwood, Vic.: Viking).

McGuire, B. (2012) Waking the Giant: How a Changing Climate Triggers Earthquakes, Tsunamis, and Volcanoes (Oxford: Oxford University Press). 
Morton, J. and Smith, N. (1999) `Planting Indigenous Species: A Subversion of Australian Eco-nationalism', in K. Neumann, N. Thomas and H. Ericksen (eds) Quicksands: Foundational Histories in Australia and Aotearoa New Zealand (Sydney: University of New South Wales Press) pp 153-175.

Mooney, H. and Hobbs, R (eds) (2000) Invasive Species in a Changing World (Washington, DC: Island Press).

New Zealand Biodiversity (undated) `Biosecurity and Biodiversity: Operation Ever Green: eradicating the white-spotted tussock moth'. [online] Available at: http://www.biodiversity.govt.nz/picture/doing/nzbs/part-three/theme-five.html (accessed $16 / 5 / 2010)$.

New Zealand Farm Forestry Association [NZFFA] (2008) `Every Moth Matters: The Eradication of White-Spotted Tussock Moth': Available at: http://www.nzffa.org.nz/images/design/Pests/Tussock-moth/tussockmothFHNews72.html (accessed 18/5/2010)

Nuridsany. C. and Perennou, M. (1996) Microcosmos: The Invisible World of Insects (New York: Stewart, Tabori \& Chang). 
Office to the Parliamentary Commissioner for the Environment [OPCE] (2000), New Zealand Under Siege: a review of the management of biosecurity risks to the environment. Wellington, [online] Available at: http://www.pce.parliament.nz/publications/all-publications/new-zealand-under-siege-a$\underline{\text { review-of-the-management-of-biosecurity-risks-to-the-environment-3 }}$ (accessed 1 November 2011).

Palladino, P., Mitman, G., Jansen, S., and Russell, E. (2003) `Chemicals in the Field: Review Symposium: Edmund Russell, War and Nature', Metascience 12 pp. 3-23.

Pennings, C., Mooney, H. and Williamson, M. (2010) Bioinvasion and Globalization: Ecology, Economics, Management, and Policy (Oxford: Oxford University Press)

Smith, N. (2005) Uneven Development: Nature, Capital and the Production of Space (Oxford: Basil Blackwell).

Rolls, E. (1969) They All Ran Wild: The Story of Pests on the Land in Australia (Sydney: Angus and Robertson).

Russell, E. (2001) War and Nature: Fighting Humans and Insects with Chemicals from World War I to Silent Spring (Cambridge: Cambridge University Press).

Thacker E, (2005) 'Nomos, nosos and bios” Culture Machine 7 [online] Available at: http://culturemachine.tees.ac.uk/frm f1.htm (accessed 1 November 2011). 
Thomson, G. (1922) The Naturalisation of Animals \& Plants in New Zealand

(Cambridge: Cambridge University Press).

Williams, P. and Timmins, S. (2002) `Economic Impacts of Weeds in New Zealand', in Pimental, D. (ed) Biological invasions: economic and environmental costs of alien plant, animal, and microbe species (Boca Raton, FL : CRC Press) pp. 175 - 184.

\footnotetext{
i There was degree of public opposition to the aerial spraying programme in the Auckland's eastern suburbs. Public opposition became more organized and vociferous in response to the use of the same insecticide in West Auckland in 1999 against the painted apple moth. See Ginsburg (2006) for a critical perspective on the use of Bacillus Thuringiensis Kurstaki in aerial spraying programmes.

${ }^{\text {ii }}$ For a more philosophical reading of the 'assemblage' of insects and flowering plants, see Deleuze and Guattari (1987: 10).
} 